\title{
ART THERAPY TO REDUCE DEPRESSION DUE TO DOMESTIC VIOLENCE AT "X" COMMUNITY IN AMBON
}

\author{
Violenta Soukotta ${ }^{1}$, Monty P. Satiadarma ${ }^{2}$ \\ ${ }^{1}$ Fakultas Psikologi, Universitas Tarumanagara Jakarta \\ Email: \\ ${ }^{2}$ Fakultas Psikologi, Universitas Tarumanagara Jakarta \\ Email: montys@fpsi.untar.ac.id
}

\begin{abstract}
This research is aimed to the practice of Art Therapy to reduce Depression due to Domestic Violence of " $X$ " Community in Ambon. Individuals undergoing domestic violence are at high risk of having many negative psychological impacts. One of its impact is depression. Individuals with depression due to domestic violence need to get a social support and psychotherapy. Art Therapy is one of a form of psychotherapy that can be suggested to treat depressed individuals. This study used qualitative research method and was conducted from April $22^{\text {nd }} 2017$ to May $22^{\text {nd }}$ 2017. The participants in this study were three (3) women who had been undergoing domestic violence for some years. The result of this study showed that art therapy had reduced the level of depression of the three participants. Art therapy hass affected participants in these areas: (a) gaining self-knowledge, (b) medium of catharsis and relaxation, (c) expression of emotions and feelings, (d) facilitating self development, (e) stimulating self awareness, (f) enhancing self confidence through the success of creating the art works, $(g)$ reducing stress and boredom. The therapeutic relations bonded between the participants and researcher might also have affected participants through their feelings of being helped and receiving deep concern from others.
\end{abstract}

Keywords: Art therapy, Depression, Domestic Violence

\begin{abstract}
ABSTRAK
Penelitian ini bertujuan untuk mempraktekkan Terapi Seni demi mengurangi Depresi akibat Kekerasan Dalam Rumah Tangga pada Komunitas " $X$ " di Ambon. Individu yang mengalami kekerasan dalam rumah tangga memiliki resiko tinggi mengalami banyak dampak psikologis negatif. Salah satu dampaknya adalah depresi. Individu yang mengalami depresi akibat kekerasan dalam rumah tangga perlu mendapatkan dukungan sosial dan psikoterapi. Terapi seni adalah salah satu bentuk psikoterapi yang dapat disarankan untuk mengobati individu yang mengalami depresi. Penelitian ini menggunakan metode penelitian kualitatif dan dilakukan mulai tanggal 22 April 2017 sampai dengan 22 Mei 2017. Partisipan dalam penelitian ini adalah tiga (3) wanita yang telah mengalami kekerasan dalam rumah tangga selama beberapa tahun. Hasil penelitian ini menunjukkan bahwa terapi seni telah mengurangi tingkat depresi pada tiga partisipan tersebut. Terapi seni telah mempengaruhi partisipan pada area berikut: (a) mendapatkan pengertian diri, (b) media katarsis dan relaksasi, (c) ekspresi emosi dan perasaan, (d) memfasilitasi pengembangan diri, (e) merangsang kesadaran diri, (f) meningkatkan kepercayaan diri melalui keberhasilan menciptakan karya seni, (g) mengurangi stres dan kebosanan. Hubungan terapeutik yang dijalin antara peserta dan peneliti mungkin juga telah mempengaruhi partisipan melalui perasaan tertolong dan menerima perhatian mendalam dari orang lain.

Kata kunci: Terapi seni, Depresi, Kekerasan Dalam Rumah Tangga
\end{abstract}

\section{PENDAHULUAN}

\section{Latar Belakang}

Kekerasan Dalam Rumah Tangga (KDRT) mengalami peningkatan dari tahun ke tahun. Korban kekerasan dalam rumah tangga atau KDRT pada umumnya di dominasi oleh anak-anak dan perempuan. Di tahun 2015, terdapat 321.752 kasus KTP (Kekerasan Terhadap Perempuan) yang bersumber pada data kasus atau perkara yang ditangani oleh Pengadilan Agama atau Badan 
Peradilan Agama (PA-BADILAG). Dari jumlah tersebut, jenis kekerasan adalah kekerasan yang terjadi di ranah personal. Dari data PA-BADILAG tercatat sejumlah 305.535 (95\%) kasus kekerasan terjadi dalam ranah KDRT. Sementara dari 16.217 kasus yang masuk dari lembaga layanan mitra Komnas Perempuan, kekerasan yang terjadi di ranah KDRT tercatat $69 \%$ atau sebanyak 11.207 kasus.

Pengaruh sosial budaya dalam masyarakat menempatkan perempuan dan anak-anak rentan terhadap ketidakberdayaan termasuk kekerasan (Suswandari, 2007). Kekerasan pada perempuan terjadi karena ketidakadilan gender di mana ada perbedaan peran antara perempuan dan laki-laki di masyarakat yang menempatkan perempuan dalam status lebih rendah dari laki-laki. Hak istimewa yang dimiliki laki-laki seolah-olah menjadikan perempuan sebagai barang milik laki-laki yang berhak untuk diperlakukan semena-mena termasuk dengan cara kekerasan (Kolibonso \& Purniati, 2002).

Situasi pasca konflik di Ambon membuat semua anggota masyarakat rentan akan kekerasan. Kemarahan, frustasi, ketakutan akan masa depan, semuanya menyebabkan orang menjadi lebih mudah marah. Sementara itu, sumber-sumber ekonomi dan lembaga-lembaga pelayanan sosial tidak berfungsi dengan baik. Menurut data dari lembaga kajian dan advokasi pemberdayaan perempuan GASIRA di Ambon, pada tahun 2015 menangani kasus pelecehan seksual sebanyak 17 kasus, perkosaan 16 kasus, dan KDRT 13 kasus. Meski demikian, kekerasan terhadap perempuan, sering dianggap tidak pantas atau merupakan aib untuk dibicarakan apalagi untuk disinggung.

Menurut ketua GASIRA di Ambon, banyaknya kasus kekerasan yang terdapat di Ambon membuat sekelompok volunter dari Belanda Stitching Save Home memberikan perhatian dan mulai melakukan konsolidasi bersama GASIRA untuk membuat suatu tempat persinggahan bagi korban kekerasan anak dan perempuan berupa Rumah Aman. Rumah Aman, merupakan tempat yang menampung korban kekerasan anak maupun perempuan. Kinerja Sistem Rumah Aman melihat sejauh mana kebutuhan korban dalam masa penanganan. Jika korban tidak merasa aman dalam keluarga, Rumah Aman dapat menjadi tempat berlindung hingga mereka benar-benar memperoleh rasa aman dalam dirinya. Setelah ditangani di Rumah Aman, korban dapat kembali kepada keluarga. Namun, jika masih belum merasa aman, maka ada petugas dari Rumah Aman yang akan melakukan pengawasan ke rumah korban dan melakukan pendampingan, sehingga korban tetap merasakan aman.

Kebanyakan korban yang masuk di Rumah Aman karena pelaporan atau rujukan dari masyarakat setempat. Kondisi ini dipengaruhi oleh kesadaran dan kepedulian masyarakat yang mulai meningkat akan tindakan KDRT. Selain itu peran aktif lembaga atau instansi terkait dalam mengungkap kasus tindak kekerasan dan menanganinya juga membantu terungkapnya kasuskasus tindak kekerasan. Meskipun demikian, masih banyak kasus tindak kekerasan terutama KDRT yang belum terungkap sehingga merupakan fenomena gunung es. Saat ini, KDRT mulai memperoleh perhatian dari Pemerintah Indonesia, yaitu dengan pengesahan Undang-Undang Anti Kekerasan dalam Rumah Tangga No. 23 Tahun 2004. Adanya Undang Undang tersebut 
mendorong istri untuk menghentikan kekerasan yang dialaminya. Salah satu hal yang dipilih istri adalah dengan menempuh jalur perdata (mengakhiri pernikahan) daripada pidana (melaporkan suami kepada pihak terkait). Cara ini dianggap istri sebagai tindakan yang cepat dan aman baginya (Kolibonso, 2002).

Dari beberapa kasus yang terungkap baik melalui media cetak maupun elektronik, kebanyakan para korban tidak melaporkan tindak kekerasan yang dialaminya sendiri. Akan tetapi, ada pihak lain seperti tetangga maupun saudara yang membantu korban untuk mendapatkan bantuan atau penanganan. Pelaporan untuk mendapatkan penanganan atau bantuan biasanya dilakukan setelah kondisi korban cukup parah atau tindak kekerasan yang terjadi telah dilakukan dalam kurun waktu yang cukup lama atau telah dilakukan berulang-ulang. Pada umumnya korban tidak segera berusaha mendapatkan pertolongan atau bantuan dipengaruhi karena mereka ingin mempertahankan rumah tangganya dan anak-anak, rasa tidak berdaya atau tidak mempunyai kekuatan untuk melawan, maupun meminta pertolongan sehingga korban kekerasan cenderung bersikap pasif (Kristyanti, 2004). Payne dan Linda (2009) dalam penelitiannya terkait alasan perempuan bertahan dalam kekerasan rumah tangga dan kekerasan terhadap perempuan menjelaskan bahwa ketika tindakan kekerasan baru dialami untuk pertama kalinya, seorang perempuan akan cenderung untuk berusaha melawan, berbicara dengan pelaku untuk menghentikan tindakannya, dan usaha yang lainnya. Akan tetapi, ketika kekerasan tersebut terusmenerus dilakukan banyak perempuan menjadi pasif, menahan emosinya, dan akhirnya bertahan hidup dalam tindak kekerasan.

Menurut WHO, kekerasan adalah penggunaan kekuatan fisik dan kekuasaan, ancaman atau tindakan terhadap diri sendiri, perorangan atau sekelompok orang atau masyarakat yang mengakibatkan memar atau trauma, kematian, kerugian psikologis, kelainan perkembangan atau perampasan hak. Banyak perempuan yang mengalami tindak kekerasan, baik dari suami, ayah maupun orang terdekat. Perempuan sebagai korban dalam hal ini sering hanya berdiam diri dan menerima tindak kekerasan tersebut. Bagai gunung es, data kekerasan yang tercatat jauh lebih sedikit dari yang seharusnya dilaporkan karena tidak semua perempuan yang mengalami kekerasan bersedia melaporkan kasusnya. Mereka lebih banyak mendiamkan permasalahannya untuk menutupi aib keluarganya. Korban kekerasan dalam rumah tangga yang sebagian besar adalah perempuan dimana posisinya yang enggan untuk melakukan pengaduan. Bagi mereka, membutuhkan keberanian yang sangat besar untuk memutuskan pengaduan atas kelakuan suami mereka. Korban akan berpikir berulang kali untuk melaporkan tindak pidana yang dialaminya. Keadaan tertekan dan ketergantungan hidup biasanya yang menjadi alasan terbesar.

Keberadaan perangkat hukum seharusnya bisa digunakan semaksimal mungkin untuk membantu mengupayakan penyelesaian kasus kekerasan terhadap perempuan. Apabila penegak hukum yang menangani perkara menyadari keseriusan masalahnya, maka perlakuan hukum yang setimpal dapat diberikan pada pelaku tindak kekerasan terhadap perempuan. Dalam kenyataannya, hal tersebut sangat jarang terjadi. Alasan utamanya antara lain adalah para penegak hukum yang tidak 
peka gender dan tidak punya keberpihakan pada kasus kekerasan terhadap perempuan (Poerwandari, 2004).

Ketika seorang perempuan bertahan dalam suatu lingkungan tempat dirinya menerima tindak kekerasan secara terus-menerus akan mengakibatkan efek psikologis tersendiri. Kepercayaan diri yang rendah, stres, trauma bahkan hingga mengalami depresi menjadi efek dari tindak kekerasan yang dialami oleh seorang perempuan. Dutton, et, al., (2005), telah mengidentifikasikan depresi sebagai reaksi psikologis yang disebabkan oleh pengalaman traumatik, termasuk diantaranya mengalami kekerasan dalam rumah tangga. Perempuan yang mengalami depresi cenderung memiliki gangguan pola tidur dan pola makan. Selain itu, mereka cenderung kurang memiliki motivasi dalam beraktifitas atau bersosialisasi dengan lingkungan sekitar. Perempuan yang telah terdiagnosa mayor depresi yang disebabkan kekerasan dalam rumah tangga berjumlah sekitar 60\%. Cascardi (dikutip oleh Dutton, et, al., 2005) menemukan bahwa kekerasan fisik berat dapat menyebabkan meningkatnya level depresi. Keterkaitan hubungan antara kekerasan emosional dan kekerasan fisik turut serta dapat meningkatkan level depresi. Dutton, et, al., (2005) juga menemukan bahwa perempuan yang mengalami kekerasan seksual selama bertahun-tahun akan meningkat level depresinya. Penelitian yang dilakukan oleh Carlson, Anne dan Deborah (2003) terhadap 557 perempuan berusia antara 18 sampai 44 tahun yang mengalami kekerasan dalam rumah tangga menemukan bahwa kekerasan fisik dan kekerasan seksual membuat meningkatnya level depresi dan kecemasan.

Oleh karena itu, intervensi psikologis sangat diperlukan bagi individu yang mengalami depresi akibat tindak kekerasan dalam rumah tangga. Ada berbagai bentuk pendekatan dan metode dalam terapis psikologis, salah satunya digunakan art therapy. Art therapy merupakan suatu bentuk psikoterapi yang dapat disarankan pada individu yang mengalami depresi. Menurut Malchiodi (2001), mengatakan bahwa art therapy dapat memberikan relaksasi pada individu yang mengalami kasus kekerasan.

Menelaah manfaat di atas, dapat disimpulkan bahwa tujuan dari art therapy pada dasarnya sama dengan bentuk psikoterapeutik lainnya, yaitu meningkatkan atau mempertahankan kesehatan mental dan kesejahteraan psikologis individu. Adapun yang membedakannya dalam art therapy, emosi, pikiran dan isu-isu pribadi dapat dituangkan dalam gambar (image) maupun symbol sehingga dapat dirasakan tidak mengancam. Selain itu, seni tidak memiliki batasan dan hal ini menjadi pilihan yang baik bagi individu dalam berbagai usia. Faktor-faktor inilah yang melatarbelakangi ketertarikkan peneliti untuk menerapkan art therapy. Penelitian ini bertujuan untuk mengetahui hasil dari penerapan art therapy sebagai intervensi untuk menurunkan depresi pada istri korban KDRT yang berada di komunitas "X" di Ambon.

\section{Rumusan Masalah}

Apakah terdapat pengurangan/penurunan tingkat depresi istri korban KDRT pada komunitas "X" di Ambon dengan menggunakan art therapy? 


\section{METODE PENELITIAN}

\section{Partisipan Penelitian}

Partisipan dalam penelitian ini adalah perempuan yang mengalami kekerasan dalam rumah tangganya (beberapa jenis kekerasan atau kombinasi dari jenis kekerasan) dan saat ini sedang mengikuti program pendampingan di Rumah Aman selama kurang lebih satu bulan. Subyek masih dalam pernikahan atau telah berpisah dari suami (baik secara resmi maupun tidak resmi). Para subyek berusia 21-41 tahun. Teknik pemilihan sampel yang digunakan adalah purposive sampling karena sampel dipilih secara langsung oleh peneliti berdasarkan kriteria yang sudah ditentukan.

\section{Desain Penelitian}

Metode yang digunakan dalam penelitian ini adalah exploratory research. Menurut Blaikie (2000), metode exploratory bertujuan untuk mendapatkan informasi mengenai sebuah fenomena yang terjadi dalam kelompok besar maupun individual dengan menggunakan pengumpulan data kualitatif (dikutip dalam Vos, 2011). Metode ini dianggap sesuai dengan tujuan awal penelitian yaitu melihat proses dan hasil penerapan art therapy untuk mengurangi depresi para istri korban KDRT yang berada di Rumah Aman. Dalam penelitian ini peneliti menggunakan data kualitatif, sehingga teknik yang digunakan dalam pengumpulan data adalah in-depth interview, observasi, dan pemberian alat tes berupa tes grafis yaitu BAUM, DAP, HTP, WZT. Peneliti juga menggunakan BDI II untuk mengukur tingkat depresi subyek penelitian. Grafis dan BDI II digunakan di awal dan akhir dari sesi terapi, tujuannya adalah untuk mengukur adanya perubahan yang terjadi pada diri subyek.

\section{Pengambilan Data}

Penelitian ini dilakukan di Rumah Aman dan tempat tinggal korban di Ambon-Maluku. Seluruh kegiatan penelitian yang terdiri dari proses wawancara, observasi, pemeriksaan psikologis terhadap setiap partisipan, dan pelaksanaan intervensi di lakukan di tempat pendampingan korban Rumah Aman dan di tempat tinggal korban. Dalam penelitian ini peneliti tidak melakukan pengukuran data bersifat kuantitatif melainkan kualitatif. Pengukuran pertama yang dilakukan oleh peneliti yaitu dengan observasi dan wawancara untuk melihat gambaran depresi dari partisipan. Melalui wawancara dan obeservasi tersebut akan diperoleh kejelasan dan keterangan mendalam dari masalah yang ingin diketahui. Selain itu peneliti juga melakukan interpretasi data yang diperoleh dari hasil tes grafis BAUM dan DAP.

\section{Pelaksanaan Penelitian}

Penelitian ini memiliki tiga (3) partisipan penelitian. Peneliti menggunakan pedoman observasi, wawancara, tes proyektif grafis (DAP, BAUM, HTP dan WZT) untuk melihat gambaran depresi, sebagai langkah awal proses screening untuk menentukan karakteristik sampel. Setelah data diperoleh, peneliti akan memilih subyek yang paling sesuai dengan karakteristik yang dibutuhkan 
dalam penelitian ini yaitu subyek dengan tingkat depresi yang tinggi. Selanjutnya, peneliti melakukan pendekatan terhadap masing-masing subyek yang sudah ditentukan dalam proses membina rapport. Peneliti melakukan serangkaian wawancara, observasi, dan pemberian informed consent untuk mengetahui persetujuan masing-masing subyek. Selanjutnya, peneliti mulai melakukan proses autoanamnesa dan alloanamnesa mengenai informasi yang akan berhubungan dengan pelaksanaan intervensi. Setelah peneliti mendapatkan informasi yang lengkap, peneliti mulai mengajak partisipan untuk mulai melakukan rangkaian intervensi art therapy. Pelaksanaan intervensi art therapy sendiri berlangsung kurang lebih selama satu bulan. Setelah pelaksanan intervensi, peneliti akan melakukan evaluasi kepada setiap partisipan, kemudian peneliti kembali memberikan setiap partisipan tes proyektif untuk melihat tingkat keberhasilan pelaksanaan intervensi art therapy yang dilaksanakan.

\section{HASIL DAN PEMBAHASAN}

\section{Subyek SU}

Kesulitan untuk mengungkapkan permasalahan rumah tangganya sering menjadi beban tersendiri bagi SU. SU mengalami pola makan dan pola tidur yang terganggu karena stress menghadapi tindak KDRT yang dilakukan suaminya. Selain itu hubungan SU dengan lingkungan sosial menjadi berubah, SU lebih sering merasa tersinggung, menjadi mudah curiga bahkan tidak ingin bergaul. Art therapy membantu SU untuk lebih mudah mengungkapkan pikiran dan perasaan yang selama ini sulit untuk diungkapkan. Kegiatan menggambar dan melukis memberikan gambaran perubahan emosi dan perilaku, yang terlihat dari perubahan tema pada setiap sesi. Selain itu, SU belajar untuk merefleksikan diri dari setiap pengalaman hidup yang ia hadapi melalui karya seni. Hal ini sesuai dengan manfaat art therapy sebagai media untuk merefleksikan diri dalam gambar (imagery).

Art therapy juga meningkatkan kepercayaan diri SU untuk berinteraksi. Interaksi yang terjalin dalam art therapy membuat SU percaya bahwa ia membutuhkan orang lain yang bisa ia percaya untuk berbagi masalah yang sedang ia hadapi. SU pun berpendapat bahwa art therapy membuat SU untuk berpikir realistis, menyadari persoalan rumah tangga yang ia hadapi tanpa harus mengakhiri hidupnya dengan percobaan bunuh diri. Dengan begitu, SU lebih fokus terhadap pengembangan diri ke arah yang lebih baik, serta mampu menghadapi setiap persoalan yang ia hadapi. Art therapy memberikan makna. Meskipun mengalami persoalan dalam rumah tangga, SU tidak boleh menyerah, melainkan memiliki keinginan untuk meningkatkan kemampuan yang dimiliki, tidak ragu-ragu untuk mengambil keputusan yang sesuai dengan harapannya ke depan.

\section{Subyek RW}

RW mengakui bahwa art therapy memberikan kesempatan untuk mengungkapkan pikiran dan perasaan yang sulit diungkapkan dengan kata-kata. Hal ini disebabkan karena selama ini, RW selalu memendam emosi negatifnya seperti rasa marah, putus asa, dan kecewa terhadap tindakan KDRT yang dilakukan suaminya. Art therapy memberikan pandangan baru terhadap RW bagaimana RW mampu mengurangi stress dan konflik di dalam dirinya. Sebelumnya, RW melihat 
dirinya sebagai sesorang yang tidak berharga, istri yang bodoh karena tidak mampu membuat suaminya bertanggung jawab terhadap anak maupun kehidupan rumah tangga mereka. Proses pembuatan karya seni melatih RW untuk menghargai pengalaman hidup yang dimiliki. RW sadar bahwa ia tetap memiliki pengalaman hidup yang dapat dikembangkan. RW termotivasi untuk mengembangkan kemampuan diri melalui kegiatan seni yang kreatif.

Selain itu, art therapy membuat RW berpikir mengenai pentingnya mengurangi depresi yang ia alami. Sebelumnya RW berpendapat bahwa ia merasa hidupnya tidak berharga, sulit untuk berinteraksi dengan orang lain, bahkan pola makan dan pola tidurnya terganggu serta kurang percaya diri.

Pada akhir sesi RW juga mengungkapkan bahwa ia lebih fokus untuk mengurus anaknya dengan lebih baik, pola makan dan pola tidur mulai membaik, serta memiliki rasa percaya diri untuk menjalin relasi dengan orang lain. Meskipun ia menyadari suaminya belum memiliki kesadaran untuk bertanggung jawab terhadap kehidupan anaknya maupun rumah tangga mereka. Selama ini RW berada di dalam situasi konflik dengan persoalan rumah tangga yang ia hadapi. Saat ini, RW memiliki keberanian untuk menyelesaikan konflik yang ia hadapi serta mengurangi emosi negatif yang ia pendam akibat tindakan KDRT yang dilakukan suaminya.

\section{Subyek FS}

FS menyatakan bahwa melalui art therapy ia mampu mengekspresikan emosi negatif (sedih, kecewa dan putus asa) dengan cara yang lebih positif. Sebelumnya FS cenderung memendam emosi negatifnya sehingga emosinya menjadi tidak stabil. FS merasa tidak percaya diri untuk berbagi persoalan hidup dengan orang lain. FS beranggapan bahwa orang lain hanya akan memandang negatif kehidupan rumah tangganya. Namun interaksi dengan terapis dalam kegiatan art therapy membuat FS menyadari bahwa masih ada orang yang bisa ia percaya untuk berbagi persoalan terkait tindak KDRT yang dilakkan suaminya.

Kegiatan art therapy memberikan gambaran pada FS mengenai permasalahan yang dialaminya selama ini. FS berpendapat bahwa hasil karyanya menjadi bukti akurat untuk memberikan penjelasan mengenai situasi yang dialami dan mencari solusi yang sesuai dari permasalahanya. Selain itu, FS beranggapan bahwa art therapy bermanfaat dalam mengekspresikan perasaannya.

\section{SIMPULAN SARAN}

Art therapy membantu subyek dalam hal sebagai berikut: (a) pengenalan diri, ketiga subyek merasa bahwa lebih dapat mengenali dirinya sendiri baik dari segi positif maupun negatif yaitu kelemahan dan kelebihannya; (b) media katarsis dan relaksasi, ketiga subyek merasakan bahwa melalui art therapy dapat membantu meringankan beban emosional yang mereka hadapi; (c) ekspresi emosi dan perasaan, subyek mampu mengekspresikan emosi dan perasaannya dengan lebih baik tanpa merasa tertekan sehingga emosinya akan tampak positif; (d) membantu perubahan diri, dengan mengetahui kekurangan yang subyek miliki setidaknya dapat meningkatkan kesejahteraan psikologis mereka; (e) menumbuhkan kesadaran diri, subyek memiliki inisiatif 
dalam menjalankan kehidupannya di masa depan; (f) meningkatkan rasa kepercayaan diri dengan keberhasilan membuat karya seni, serta $(\mathrm{g})$ mengurangi stres dan rasa jenuh, subyek meluangkan waktunya dalam menyalurkan hobi dan mencoba aktifitas yang baru. Hal ini, terlihat dari hasil karya seni, observasi perubahan perilaku, proses pada setiap sesi art therapy, wawancara dan hasil pre-test dan post-test tes grafis.

Penelitian selanjutnya disarankan untuk menggunakan subyek penelitian dengan jumlah lebih banyak untuk memperoleh temuan yang lebih lengkap. Peneliti lebih baik menggunakan dua setting lokasi komunitas pendampingan korban KDRT yang berbeda untuk dilakukanya perbandingan data dan kepentingan menjawab fenomena. Selain itu, art therapy yang dilakukan di Komunitas Rumah Aman dan tempat tinggal subjek dapat mengurangi efek terapeutik dibandingkan jika dilakukan dalam setting yang berfungsi sebagai tempat terapi. Peneliti menganjurkan jika ada penelitian serupa dengan terapi seni sebaiknya dilakukan pada ruang khusus seperti studio terapi seni atau ruang terapi.

\section{Ucapan Terima Kasih}

Peneliti mengucapkan terima kasih kepada pengurus Rumah Aman yang telah memberikan kesempatan kepada peneliti untuk melakukan penelitian di organisasi. Terlebih, rasa terimakasih Peneliti ucapkan kepada partisipan yang telah meluangkan waktu untuk mengikuti penelitian ini.

\section{REFERENSI}

Carlson, B. E., Anne, M. L., \& Deborah, C. (2003). Childhood and adult abuse among women in primary health care: Effects on mental health. Journal of Interpersonal Violence, 18, 924941.

Dutton, M. A., Khoury, M., Murphy, M., \& Bell, M. (2005). Women in intimate partner violence: Major advance and new directions. Journal of Family Psychology, 23, 191-201.

Kolibonso, R. S., \& Purniati. (2002). Panduan menyusun program radio: Kampanye hak-hak perempuan dalam rumah tangga. Jakarta: Mitra Perempuan.

Malchiodi, C. A. (2001). Handbook of art therapy. New York, NY: Guilford Press.

Poerwandari, E. K. (2004). Mengungkap selubung kekerasan: Telaah filsafat manusia. Jakarta: LPSP3 UI.

Suswandari. (2007). Konsep kekerasan terhadap perempuan dan anak. Jakarta: Sikap.

Undang-Undang No.23 tahun 2004. Penghapusan kekerasan dalam rumah tangga. Jakarta: Kiwi Mitra Utama. 
Vos, A. D., Strydom, H., Fouche, C. B., \& Delport, C. S. R. (2011). Research at grass roots for the social sciences and human service professions (4th ed.). Hatfield, ZA: Van Schaik. 